Original Article

\title{
Egg production and life history of Alona guttata Sars, 1862 (Cladocera, Chydoridae): implications for colonization of temporary ponds
}

\author{
Produção de ovos e história de vida de Alona guttata Sars, 1862 \\ (Cladocera, Chydoridae): implicações para a colonização de lagoas temporárias
}

\author{
E. E. Cortez-Silva ${ }^{*}$ (D), V. F. Souza ${ }^{a}$ (D) G. S. Santos ${ }^{a}$ (D) and E. M. Eskinazi-Sant'Anna ${ }^{a}$ (D) \\ aUniversidade Federal de Ouro Preto - UFOP, Departamento de Biodiversidade, Evolução e Meio Ambiente, Laboratório de Ecologia Aquática, \\ Conservação e Evolução, Ouro Preto, MG, Brasil
}

\begin{abstract}
Cladocerans are a diverse group of species that show rapid responses to changes in environmental conditions. This adaptive capacity has important implications for egg production and life cycle, especially in transitory environments such as temporary waterbodies. The present study investigated the life history and egg production of Alona gutatta Sars, 1862 (Crustacea, Cladocera), an abundant and frequent species from a high-altitude temporary pond (Lagoa Seca, Minas Gerais, Brazil). Newly hatched neonates were monitored in relation to time of maturation, number of eggs produced per female and time of survival. Neonates required a mean of 8 days to mature. A. guttata survived for a mean of $30.9 \pm 8.1$ days and produced 2 eggs per brood, generating a mean of $10.95 \pm 6.41$ neonates during the entire life cycle. The rapid development, short time to produce eggs and long life cycle are important adaptations to the adverse environmental conditions of temporary aquatic environments, which can contribute to the rapid colonization of Alona guttata in transitory ecosystems.
\end{abstract}

Keywords: high-altitude pond, hydroperiod, Alonidae, growth rates.

\begin{abstract}
Resumo
Os cladóceros formam um grupo diverso de espécies que apresentam respostas rápidas às mudanças nas condições ambientais. Essa capacidade adaptativa tem implicações importantes para a produção de ovos e para o ciclo de vida, especialmente em ambientes transitórios, como corpos d'água temporários. O presente estudo investigou a história de vida e a produção de ovos da espécie Alona guttata Sars, 1862 (Crustacea, Cladocera) coletada em uma lagoa temporária de altitude (Minas Gerais, Brasil). Organismos recém eclodidos foram observados (em condições de laboratório) em relação ao tempo de maturação, número de ovos produzidos por fêmea e tempo de sobrevivência. Os neonatos levaram em média 8 dias para atingir o primeiro estágio de maturação. As fêmeas produziram 2 ovos por ninhada e geraram uma média de $10,95 \pm 6,41$ neonatos durante todo o ciclo de vida. A. guttata apresentou uma média de 30,9 \pm 8,1 dias de sobrevivência. 0 rápido desenvolvimento, o pouco tempo para a produção de ovos e o ciclo de vida longo são adaptações importantes às condições ambientais adversas de ambientes aquáticos temporários, que podem contribuir para a rápida colonização de Alona guttata em ecossistemas transitórios.
\end{abstract}

Palavras-chave: poça temporária de altitude, hidroperíodo, Alonidae, taxas de crescimento.

\section{Introduction}

Temporary ponds are highly variable environments, since they remain completely dry for long periods until they fill with the arrival of the rainy season. This filling and drying regime strongly influences the population dynamics of aquatic organisms. Additionally, temporary ponds located in high-altitude areas are subject to daily fluctuations of temperature, luminosity, and radiation. These dominant environmental drivers may select species that have developed special strategies to survive and persist in harsh environmental conditions
(Beccato, 2004; Pintar and Resetarits Junior, 2018; Martins et al., 2019).

Most cladocerans may be bacterivorous, herbivorous or detritivorous, feeding upon a wide spectrum of items including organic detritus, bacteria and algae (Rocha et al., 2011; Hayashi-Martins et al., 2017). In addition to their high species diversity, this high functional diversity makes cladocerans a key group shaping food webs and community structure in shallow lakes (Lampert, 1997; Simões et al., 2009). Members of the family Chydoridae are

*e-mail: edissaecs@gmail.com

Received: April 29, 2020 - Accepted: October 1, 2020 
usually abundant in shallow lakes (Moreira et al., 2016). Their abundance can be associated with the close relationship with the dense presence of aquatic vegetation (Bolduc et al., 2016), since they are specialized in exploiting microenvironments provided by vegetation (Scheffer, 2004; Forró et al., 2008).

In spite of their high ecological importance, few studies have addressed the fundamental aspects of life history and egg production of these zooplankters, especially in tropical high-altitude aquatic environments. Study of the life cycles and reproduction of zooplankton species is essential for understanding the adaptive mechanisms that allow organisms to survive in these changeable habits. In the present study we examined aspects of the life history and egg production of Alona guttata Sars, 1862 (Chydoridae), a common and abundant species often found in small highaltitude ponds in Brazil (Santos-Wisniewski et al., 2002; Eskinazi-Sant'Anna and Pace, 2018).

\section{Material and Methods}

Zooplankton samples were obtained from a seasonal pond located in the State Park of Itacolomi (Minas Gerais state) at 1606 m.a.s.l. (20²5’52"S; 4329'12"W). The pond is an oligotrophic, slightly acid seasonal aquatic water body, with mean value of $\mathrm{pH}$ below 6.5 and mean annual water temperature of $19^{\circ} \mathrm{C}$. (Moreira et al., 2016). Samples were obtained in January 2014 by filtration of $30 \mathrm{~L}$ of water in a $68 \mu \mathrm{m}$ mesh size plankton net. The species A. guttata was identified according to (Elmoor-Loureiro, 1997; Sterza and Fernandes, 2006). In the laboratory, parthenogenetic females were sorted from the samples under stereomicroscope and reared in individual wells of 6-well tissue-culture plates (Corning®), filled with filtered water (Whatman ${ }^{\circledR}$ GFC) from the pond. The females were reared in experimental growth chambers at constant temperature $\left(22 \pm 2{ }^{\circ} \mathrm{C}\right)$ and $16: 8 \mathrm{~h}$ light/dark cycle photoperiod. Every two days the water was partially renewed. Organisms were fed with a suspension of the chlorophycean Raphidocelis subcapitata (until reach final concentration of about 104 cells. $\mathrm{ml}^{-1}$ ). Females with eggs were isolated and maintained in tissue-culture plates until release of the neonates. Then, twenty neonates were isolated in tissue-culture plates and kept in a germination chamber under the same environmental conditions described above. The neonates were observed daily under a stereomicroscope in order to determine the maturation time, number of eggs produced per female, and growth (estimated as body size). To determine body size, twenty adult females and twenty neonates were measured under an optical microscope, using an ocular eyepiece equipped with a micrometer. The growth curve of Alona guttata was estimated through the Von Bertalanffy equation, followed by the Ford-Walford adjustment (Sparre, 1998). Body size from neonates $\left(t_{0}\right)$ and adults parthenogenetic females $\left(t_{30}\right)$ were used as reference to estimate the growth curve.

\section{Results and Discussion}

In the first day of the experiment, two of the twenty neonates died, and a total of eighteen neonates could be grow up to complete development. Production of parthenogenetic eggs was recorded from the second day of culture. The neonates generated by these females required $4.92 \pm 0.26$ days to mature. After the 6th day, the neonates had eggs, which were released after 2 days (i.e., newly hatched neonates required a mean of 8 days to mature and begin reproduction). In general, each female produced 2 eggs per brood and generated a mean of $20 \pm 6.92$ neonates during its entire life cycle; the females produced a total of 360 individuals during the 37 days of the experiment (Figure 1). Each female produced a mean of $10 \pm 3.46$ broods during its life cycle. After egg production halted, females survived for $2.5 \pm 0.98$ days,

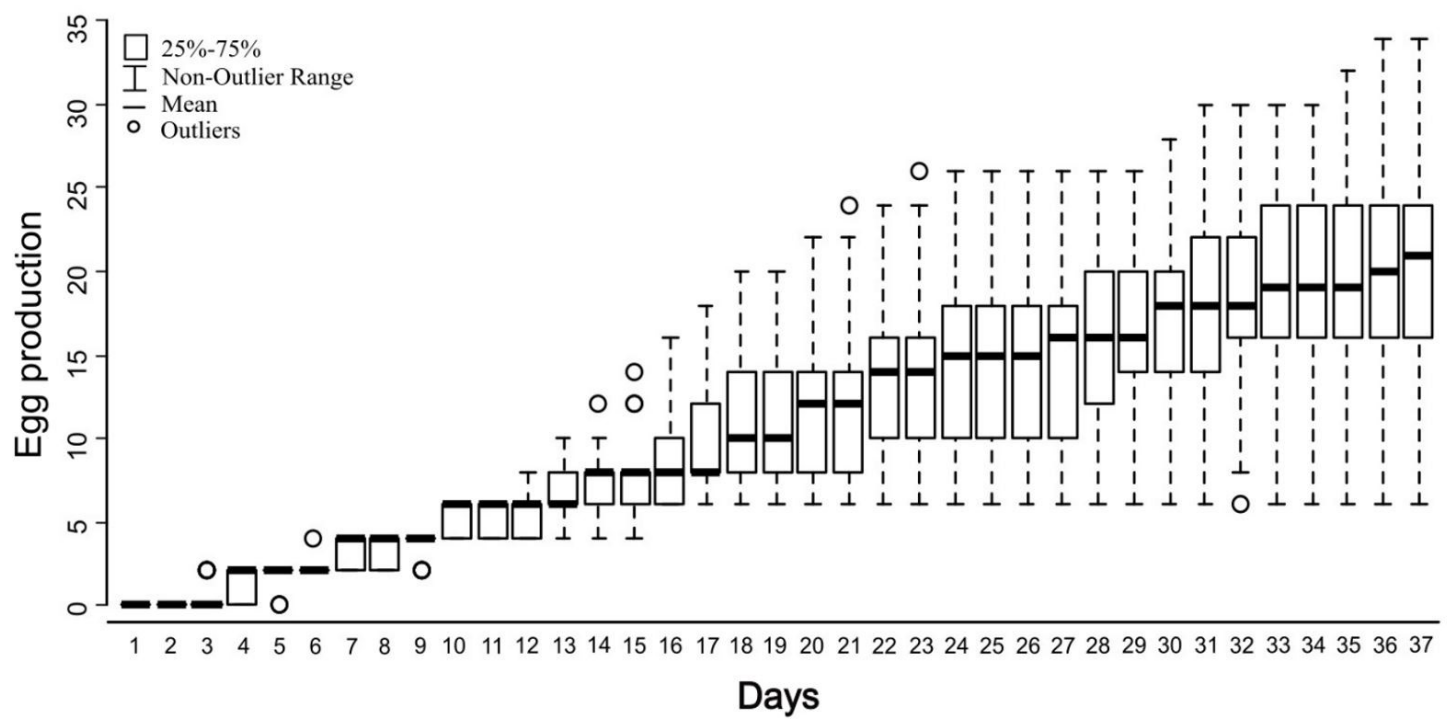

Figure 1. Reproduction aspects and life cycle parameters of Alona guttata for 18 individuals grown under laboratory conditions. (Fed with R. subcapitata, controlled temperature of $22 \pm 2{ }^{\circ} \mathrm{C}$ and photoperiod of $16 \mathrm{~h}$ light/ $8 \mathrm{~h}$ dark.) 
Table 1. Reproduction aspects and life cycle parameters of Alona guttata for 18 individuals grown under laboratory conditions. (Fed with $R$. subcapitata, controlled temperature of $22 \pm 2{ }^{\circ} \mathrm{C}$ and photoperiod of $16 \mathrm{~h}$ light $/ 8 \mathrm{~h}$ dark).

\begin{tabular}{lc}
\hline Life cycle parameters & Values \\
\hline Adult length $(\mu \mathrm{m})$ & $390 \pm 27$ \\
Embryonic Development (days) & $2 \pm 0.2$ \\
Maturation of neonates (post-embryonic) (days) & $4.92 \pm 0.26$ \\
Maximum days of life (days) & 37 \\
Maximum number of brood per female & 17 \\
Mean longevity (days) & 30.9 \\
Minimum days of life (days) & 13 \\
Minimum number of brood per female & 3 \\
Neonates length ( $\mu \mathrm{m})$ & $200 \pm 12$ \\
Primipara age (days) & $5.9 \pm 0.37$ \\
\hline
\end{tabular}

for a median of $30.9 \pm 8.1$ days of survival (Table 1 ). Neonates and adults had mean lengths of $0.2 \pm 0.01$ and $0.39 \pm 0.03 \mathrm{~mm}$, respectively.

The present results showed that $A$. guttata (Figure 2) produced fewer eggs per female than other cladoceran species such as Ceriodaphnia and Moina, which have a mean of 9 and 4 eggs per brood, respectively (Fonseca and Rocha, 2004). The egg production of A. guttata is similar to other species of Chydoridae, as seen in Table 2. The longevity of $A$. guttata (30,9 days) is higher to those of other species of Chydoridae (Santos et al., 2006; Santos Silva et al., 2014). Many factors can influence cladocerans longevity, especially water temperature, photoperiod and food quality (Santos et al., 2006; Ferrão-Filho and Azevedo, 2003). Highest temperatures may influence metabolic processes and reproduction (Ahlgren et al., 1990), and the nutritional quality and variety of food sources provided during experiments may determine growth rates, egg production and life cycle duration (Weers and Gulati, 1997). During the experiments, only one algal source food was used. Therefore, the low mortality rate observed $(<5 \%$ of total individuals), and the relatively long cycle of $A$. guttata (30.9 days) are indicative that nutritional constrains did not affect the performance of the individuals during the experiment.

A. guttata body size ranged from $190 \mu \mathrm{m}$ (neonate, lower measured value) to $450 \mu \mathrm{m}$ (higher value). The neonates had a mean size of $200 \mu \mathrm{m}( \pm 12 \mu \mathrm{m})$ and adult parthenogenetic females $390 \mu \mathrm{m}( \pm 37 \mu \mathrm{m})$ (Figure 3 and Table 1$)$. The mean size of $A$. guttata neonate was slightly lower than that registered to others Chydoridae species (Table 2). Viti et al. (2013) registered mean size of neonates of Coronatella rectangular reaching $(204 \mu \mathrm{m})$, lower than the observed for Chydorus pubescens neonates $(242 \mu \mathrm{m})$ (SantosWisniewski et al., 2006). Therefore, although neonates of $A$. guttata had shown a lower mean size in relation to others Chydoridae cladocerans, neonates growth increases substantially during the experiment. The observed mean size for parthenogenetic females of A. guttata are similar to that registered to others Chydoridae cladocerans (Melão and Rocha, 2006; Castilho et al., 2012).

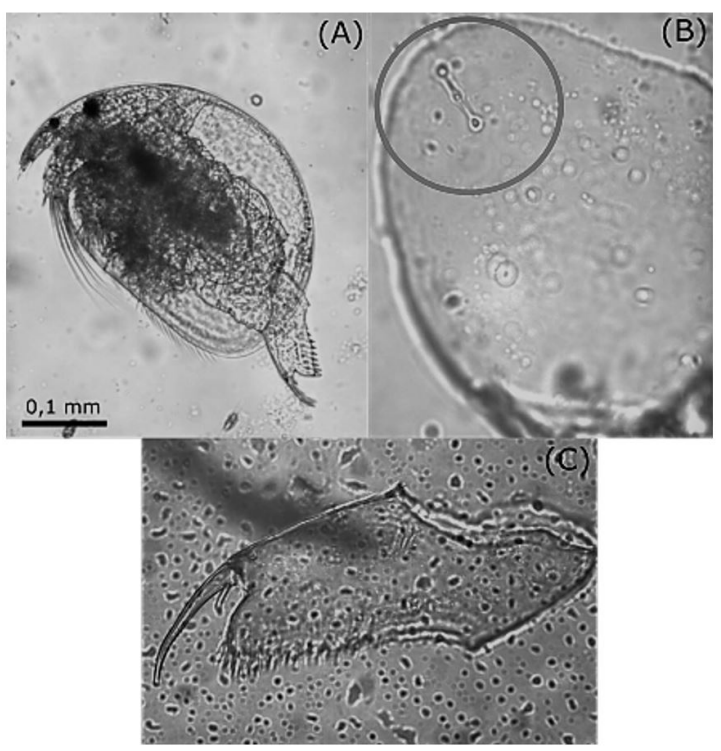

Figure 2. Alona guttata Sars, 1862: (A) parthenogenetic female; (B) head pore; (C) post-abdomen details.

Although the egg production of $A$. guttata can be considered low in relation to others species of Chydoridae (Melão and Rocha, 2006; Castilho et al., 2012), the association of longer life cycle and the constant breeding may represent an efficient life history aspect favoring the maintenance of the population and recolonization of Alona guttata in temporary ponds. In our experiments, parthenogenetic females of $A$. guttata were able to produce eggs 8 days after hatching, in addition to produce a large number of broods per female. The production of parthenogenetic eggs requires high amounts of energy (Dodson et al., 2010). Food sources to representatives of the Chydoridae family are mainly related to the biofilm attached to macrophytes. Under drastic fluctuation of the environmental conditions, typical of temporary ponds, noticeable reductions of the macrophyte banks can occurs, limiting food supply. The combination of longer life cycle and constant breeding may contribute to surpass periods 
Table 2. Comparison of embryonic development time and fertility of other species of cladocerans, reported in the literature.

\begin{tabular}{|c|c|c|c|c|c|c|c|c|c|}
\hline Species & EDD & MN & $\mathbf{A L}$ & NL & $\mathbf{L}$ & LM & $\mathbf{F}$ & FM & Reference \\
\hline $\begin{array}{l}\text { Alona } \\
\text { guttata }\end{array}$ & $2 \pm 0.2$ & $4.92 \pm 0.2$ & $390 \pm 3$ & $200 \pm 10$ & 37 & $30 \pm 8.1$ & 2.0 eggs/female & $20 \pm 6.92$ & Present study \\
\hline $\begin{array}{l}\text { Alona } \\
\text { iheringula }\end{array}$ & $1.79 \pm 0.2$ & $3.24 \pm 0.6$ & 510 & $288 \pm 19$ & 54 & $46 \pm 6$ & 2.0 eggs/female & $47.6 \pm 6.3$ & $\begin{array}{c}\text { Santos Silva et al. } \\
\text { (2014) }\end{array}$ \\
\hline $\begin{array}{l}\text { Ceriodaphnia } \\
\text { silvestrii }\end{array}$ & - & $3.05 \pm 0.7$ & $1040 \pm 4$ & $370 \pm 30$ & - & $\begin{array}{c}29.8 \pm 5.9 \\
0.37\end{array}$ & $\begin{array}{c}9.46 \pm 4.17 \text { eggs } / \\
\text { female }\end{array}$ & - & $\begin{array}{c}\text { Fonseca and Rocha } \\
(2004)\end{array}$ \\
\hline $\begin{array}{l}\text { Chydorus } \\
\text { dentifer }\end{array}$ & 1.9 & - & - & - & - & 25.4 & 2.0 eggs/female & 22.3 & $\begin{array}{c}\text { Santos- } \\
\text { Wisniewski et al. } \\
\text { (2006) }\end{array}$ \\
\hline $\begin{array}{l}\text { Chydorus } \\
\text { pubescens }\end{array}$ & $1.96 \pm 0.1$ & $2.37 \pm 0.43$ & 389 & $241 \pm 17.7$ & 31 & $25.4 \pm 4.6$ & 2.0 eggs/female & $22.3 \pm 5.1$ & $\begin{array}{c}\text { Santos- } \\
\text { Wisniewski et al. } \\
\text { (2006) }\end{array}$ \\
\hline $\begin{array}{l}\text { Coronatella } \\
\text { rectangula }\end{array}$ & $1.68 \pm 0.1$ & $2.48 \pm 0.4$ & $434 \pm 14$ & $204 \pm 30$ & 46 & $28.0 \pm 9.3$ & 2.0 eeggs/female & $27.8 \pm 9$ & Viti et al. (2013) \\
\hline $\begin{array}{l}\text { Daphnia } \\
\text { laevis }\end{array}$ & - & $10.20 \pm 3$ & $1860 \pm 4$ & $62 \pm 10$ & - & $28.3 \pm 0.1$ & $\begin{array}{c}4.45 \pm 1.06 \text { eggs } / \\
\text { female }\end{array}$ & 65 & Rocha et al. (2016) \\
\hline $\begin{array}{l}\text { Macrothrix } \\
\text { flabelliger }\end{array}$ & 4.9 & 3.5 & 1070 & $310 \pm 18$ & 27 & $12.7 \pm 8.5$ & $\begin{array}{l}13.6 \pm 4.7 \text { eggs } / \\
\text { female }\end{array}$ & $122.3 \pm 0.0$ & $\begin{array}{l}\text { Güntzel et al. } \\
\text { (2003) }\end{array}$ \\
\hline $\begin{array}{l}\text { Oxyurella } \\
\text { longicaudis }\end{array}$ & $2.30 \pm 0.5$ & 5.2 & $883 \pm 27.7$ & $503 \pm 52.77$ & 58 & $46.9 \pm 9.0$ & 2.0 eggs/female & $22.55 \pm 3.98$ & $\begin{array}{c}\text { Almeida } \\
\text { Castilho et al. } \\
\text { (2015) }\end{array}$ \\
\hline $\begin{array}{l}\text { Scapholeberis } \\
\text { armata freyi }\end{array}$ & $1.9 \pm 0.37$ & $5.86 \pm 1$ & $827 \pm 21$ & $281 \pm 21$ & 31 & $23 \pm 4$ & $8 \pm 3$ eggs/female & $47.58 \pm 6.27$ & $\begin{array}{l}\text { Castilho et al. } \\
\text { (2012) }\end{array}$ \\
\hline
\end{tabular}

EDD: Embryonic Development (days); MN: Maturation of neonates (post-embryonic in days); AL: Adult length ( $\mu \mathrm{m}) ;$ NL: Neonates length ( $\mu \mathrm{m})$; L: Longevity (days); LM: Longevity Mean (days); F: Eggs number; FM: Mean number of eggs in the whole life cycle.

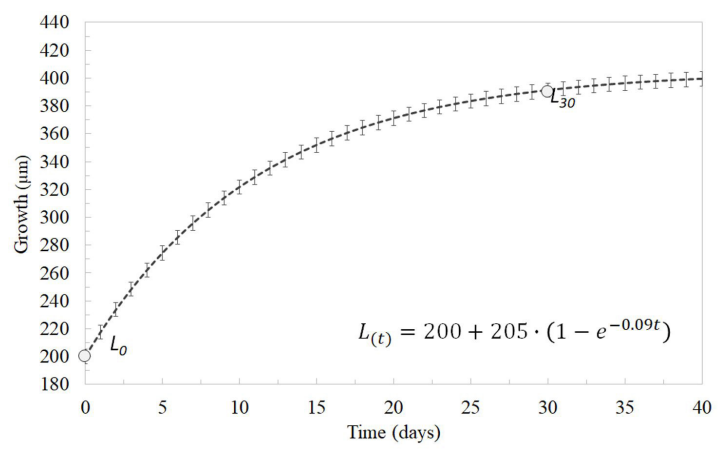

Figure 3. Growth curve of Alona guttata in experimental conditions of controlled light conditions. (Fed with R. subcapitata, controlled temperature of $22 \pm 2{ }^{\circ} \mathrm{C}$ and photoperiod of $16 \mathrm{~h}$ light $/ 8 \mathrm{~h}$ dark.)

of extreme variation of environmental conditions, ensuring the constant growth of the population.

The short time that females of $A$. guttata survived after they stopped producing new eggs is similar to records for other species of cladocerans, such as Chydorus pubescens and Oxyurella longicaudis (Santos-Wisniewski et al., 2006; Almeida Castilho et al., 2015). Our study indicates that A. guttata presented a rapid body development, which suggests that this species allocates high amounts of energy to growth, to allow early reproduction in its life cycle. The rapid development and short time that neonates of $A$. guttata require to mature and generate eggs are important adaptations to the harsh environmental conditions in temporary ponds, which aid it in colonizing and producing resting eggs in these systems. The results of this study are pertinent to aspects of the population dynamics of A. guttata, an important member of food webs of high-altitude temporary ponds.

\section{Acknowledgements}

Thanks to the Federal University of Ouro Preto (UFOP) for logistical support during the field work. To the Dean of Research of UFOP for granting a scholarship to Vivian Santos. Many thanks to Dr. Janet Reid for English revision and suggestions to the manuscript. We are very grateful to anonymous reviewers for comments on a previous version of the macnuscript.

\section{References}

AHLGREN, G., LUNDSTEDT, L., BRETT, M.T.C. and FORSBERG, C., 1990. Lipid composition and food quality of some freshwater phytoplankton for cladoceran zooplankters. Journal of Plankton Research, vol. 12, no. 4, pp. 809-818. http://dx.doi.org/10.1093/plankt/12.4.809.

ALMEIDA CASTILHO, M.C., SANTOS WISNIEWSKI, M.J., DE ABREU, C.B. and ORLANDO, T.C., 2015. Life history and DNA barcode of Oxyurella longicaudis (Birgei, 1910) (Cladocera, Anomopoda, Chydoridae). Zoological Studies, vol. 54, e20. http://dx.doi. org/10.1186/s40555-014-0104-5. PMid:31966107.

BECCATO, M.A.B., 2004. Elaboração participativa de uma proposta de reestruturação do sistema de tratamento de esgoto da 
Comunidade do Marujá-Parque Estadual da Ilha Cardoso-SP. São Carlos: Universidade de São Paulo, 292 p. Dissertação de Mestrado em Ciências da Engenharia Ambiental. https://doi. org/10.11606/D.18.2004.tde-07082005-183900.

BOLDUC, P., BERTOLO, A. and PINEL-ALLOUL, B., 2016. Does submerged aquatic vegetation shape zooplankton community structure and functional diversity? A test with a shallow fluvial lake system. Hydrobiologia, vol. 778, no. 1, pp. 151-165. http:// dx.doi.org/10.1007/s10750-016-2663-4.

CASTILHO, M.C.D.A., WISNIEWSKI, C. and SANTOS-WISNIEWSKI, M.J.D., 2012. Life cycle of Scapholeberis armata freyi Dumont \& Pensaert, 1983 (Cladocera, Daphnidae). Biota Neotropica, vol. 12, no. 4, pp. 56-60. http://dx.doi.org/10.1590/S1676-06032012000400005.

DODSON, S.L., CÁCERES, C.E. and ROGERS, D.C. 2010. Cladocera and other Branchiopoda. In: J. H. THORP and A. P. COVICH, eds. Ecology and classification of North American freshwater invertebrates. San Diego: Elsevier, pp. 773-827. http://dx.doi. org/10.1016/B978-0-12-374855-3.00020-0.

ELMOOR-LOUREIRO, L.M.A., 1997. Manual de identificação de cladóceros límnicos do Brasil. Brasilia: Universa.

ESKINAZI-SANT'ANNA, E.M. and PACE, M.L., 2018. The potential of the zooplankton resting-stage bank to restore communities in permanent and temporary waterbodies. Journal of Plankton Research, vol. 40, no. 4, pp. 458-470. http://dx.doi.org/10.1093/ plankt/fby023.

FERRÃO-FILHO, A.S. and AZEVEDO, S.M., 2003. Effects of unicelular and colonial forms of toxic Microcystis aeruginosa from laboratory cultures and natural populations on tropical cladocerans. Aquatic Ecology, vol. 37, no. 1, pp. 23-35. http:// dx.doi.org/10.1023/A:1022133329940.

FONSECA, A.L. and ROCHA, O., 2004. The life-cycle of Ceriodaphnia silvestrii Daday, 1902, a Neotropical endemic species (Crustacea, Cladocera, Daphnidae). Acta Limnologica Brasiliensia, vol. 16, no. 4, pp. 319-328. http://dx.doi.org/10.1093/plankt/fby023.

FORRÓ, L., KOROVCHINSKY, N.M., KOTOV, A.A. and PETRUSEK, A., 2008. Global diversity of cladocerans (Cladocera; Crustacea) in freshwater. Hydrobiologia, vol. 595, no. 1, pp. 177-184. http:// dx.doi.org/10.1007/s10750-007-9013-5.

GÜNTZEL, A.M., MATSUMURA-TUNDISI, T. and ROCHA, O., 2003. Life cycle of Macrothrix flabelligera Smirnov, 1992 (Cladocera, Macrothricidae), recently reported in the Neotropical region. Hydrobiologia, vol. 490, no. 1-3, pp. 87-92. http://dx.doi. org/10.1023/A:1023414612650.

HAYASHI-MARTINS, L.H., MANSANO, A.S., HISATUGO, K.F., ROCHA, O. and SELEGHIM, M.H.R., 2017. "In vitro" evaluation of the bacterivore potential of three Cladoceran species occurring in tropical and subtropical regions. Brazilian Journal of Biology = Revista Brasileira de Biologia, vol. 77, no. 4, pp. 840-847. http:// dx.doi.org/10.1590/1519-6984.02716. PMid:28355388.

LAMPERT, W., 1997. Zooplankton research: the contribution of limnology to general ecological paradigms. Aquatic Ecology, vol. 31, no. 1, pp. 19-27. http://dx.doi.org/10.1023/A:1009943402621.

MARTINS, K.P., BANDEIRA, M.G.S., PALMA-SILVA, C. and ALBERTONI, E.F., 2019. Microcrustacean metacommunities in urban temporary ponds. Aquatic Sciences, vol. 81, no. 4, pp. 56. http:// dx.doi.org/10.1007/s00027-019-0655-y.

MELÃO, M.G.G. and ROCHA, O., 2006. Life history, population dynamics, standing biomass and production of Bosminopsis deitersi (Cladocera) in a shallow tropical reservoir. Acta Limnologica Brasiliensia, vol. 18, no. 4, pp. 433-450.

MOREIRA, R.A., ROCHA, O., SANTOS, R.M., DIAS, E.S., MOREIRA, F.W.A. and ESKINAZI-SANT'ANNA, E.M., 2016. Composition, Body-Size Structure and Biomass of Zooplankton in a High-
Elevation Temporary Pond (Minas Gerais, Brazil). Oecologia Australis, vol. 20, no. 2, pp. 81-93. http://dx.doi.org/10.4257/ oeco.2016.2002.06.

PINTAR, M.R. and RESETARITS, W.J. Jr., 2018. Filling ephemeral ponds affects development and phenotypic expression in Ambystoma talpoideum. Freshwater Biology, vol. 63, no. 9, pp. 1173-1183. http://dx.doi.org/10.1111/fwb.13125.

ROCHA, O., SANTOS-WISNIEWSKI, M.J. and MATSUMURA-TUNDISI, T., 2011. Checklist of fresh-water Cladocera from São Paulo State, Brazil. Biota Neotropica, vol. 11, suppl. 1, pp. 571-592. http:// dx.doi.org/10.1590/S1676-06032011000500024.

ROCHA, G.S., TONIETTO, A.E., LOMBARDI, A.T. and MELÃO, M.G.G., 2016. Efeito de alimentos contaminados com cobre no ciclo de vida e produção secundária de Daphnia laevis. Ecotoxicologia e Segurança Ambiental, vol. 133, pp. 235-242. http://dx.doi. org/10.1016/j.ecoenv.2016.07.011. PMid:27472028.

SANTOS, M., MELÃO, M.G.G. and LOMBARDI, A.T., 2006. Life history characteristics and production of Ceriodaphnia silvestrii Daday (Crustacea, Cladocera) under different experimental conditions. Acta Limnologica Brasiliensia, vol. 18, no. 3, pp. 199-212.

SANTOS SILVA, E., ABREU, C.B., ORLANDO, T.C., WISNIEWSKI, C. and SANTOS-WISNIEWSKI, M.J., 2014. Alona iheringula Sinev and Kotov, 2004 (Crustacea, Anomopoda, Chydoridae, Aloninae): life cycle and DNA barcode with implications for the taxonomy of the Aloninae subfamily. PLoS One, vol. 9, no. 5, e97050. http:// dx.doi.org/10.1371/journal.pone.0097050. PMid:24878503.

SANTOS-WISNIEWSKI, M.J., ROCHA, O., GÜNTZEL, A.M. and MATSUMURA-TUNDISI, T., 2002. Cladocera Chydoridae of high altitude water bodies (Serra da Mantiqueira), in Brazil. Brazilian Journal of Biology = Revista Brasileira de Biologia, vol. 62, no. 4A, pp. 681-687. http://dx.doi.org/10.1590/S151969842002000400016. PMid:12659018.

SANTOS-WISNIEWSKI, M.J., ROCHA, O. and MATSUMURA-TUNDISI, T., 2006. Aspects of the life cycle of Chydorus pubescens Sars, 1901 (Cladocera, Chydoridae). Acta Limnologica Brasiliensia, vol. 18, pp. 305-310.

SCHEFFER, M., 2004. Ecology of shallow lakes. Dordrecht: Kluwer Academic Publishers. http://dx.doi.org/10.1007/978-1-4020-3154-0.

SIMÕES, N.R., ROBERTSON, B.A., LANSAC-TÔHA, F.A., TAKAHASHI, E.M., BONECKER, C.C., VELHO, L.F.M. and JOKO, C.Y., 2009. Exotic species of zooplankton in the upper Paraná river floodplain, Daphnia lumholtzi Sars, 1885 (Crustacea: branchiopoda). Brazilian Journal of Biology = Revista Brasileira de Biologia, vol. 69, no. 2, suppl., pp. 551-558. http://dx.doi.org/10.1590/S151969842009000300010. PMid:19738962.

SPARRE, P., 1998. Introduction to tropical fish stock assessment. Part 1: manual. Rome: FAO, 407 p. FAO Fisheries Technical Paper, no. 306.

STERZA, J.M. and FERNANDES, L.L., 2006. Distribution and Abundance of Cladocera (Branchiopoda) in the Paraíba Do Sul River Estuary, Rio de Janeiro, Brazil. Brazilian Journal of Oceanography, vol. 54, no. 4, pp. 193-204. http://dx.doi. org/10.1590/S1679-87592006000300003.

VITI, T., WISNIEWSKI, C., ORLANDO, T.C. and SANTOS-WISNIEWSKI, M.J.D., 2013. Life history, biomass and production of Coronatella rectangula (Branchiopoda, Anomopoda, Chydoridae) from Minas Gerais. Iheringia. Série Zoologia, vol. 103, no. 2, pp. 110117. http://dx.doi.org/10.1590/S0073-47212013000200005.

WEERS, P.M.M. and GULATI, R.D., 1997. Effect of the addition of polyunsaturated fatty acids to the diet on the growth and fecundity of Daphnia galeata. Freshwater Biology, vol. 38, no. 3, pp. 721-729. http://dx.doi.org/10.1046/j.1365-2427.1997.00237.x. 